\section{E51}

.1392

vol. 10

no. 9

NMA!

\section{INDIAN NOTES VD MONOGRAPHS}

EdITED BY F. W. Hodge

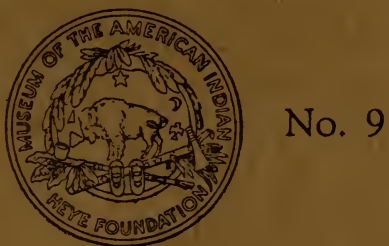

A SERIES OF PUBLICA. TIONS RELATING TO THE AMERICAN ABORIGINES

DECORATIVE ART OF THE TÊTES DE BOULE OF QUEBEC

BY

D. S. DAVIDSON

NEW YORK

MUSEUM OF THE AMERICAN INDIAN HEYE FOUNDATION

1928 
This series of Indian Notes AND MonoGRAPHS is devoted to the publication of the results of studies by members of the staff and by collaborators of the Museum of the American Indian, Heye Foundation, and is uniform with Hispanic Notes and Monographs, published by the Hispanic Society of America, with which organization this Museum is in cordial coöperation.

A List of Publications of the Museum will be sent on request.

Museum of the American Indian

HeYe Foundation

BRoADWAY AT 155Th St.

New York City 


\section{INDIAN NOTES \\ AND MONOGRAPHS}

Edited by F. W. Hodge

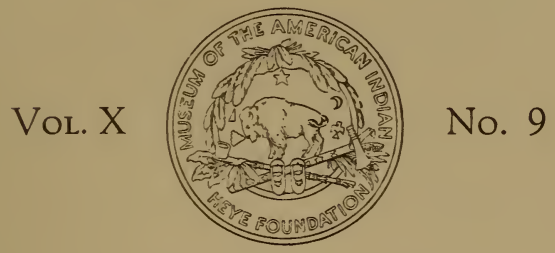

A SERIES OF PUBLICATIONS RELATING TO THE AMERICAN ABORIGINES

DECORATIVE ART OF THE TÊTES DE BOULE OF QUEBEC

BY

D. S. DAVIDSON

NEW YORK

MUSEUM OF THE AMERICAN INDIAN

HEYE FOUNDATION

1928 
LANGASERR PPESS, INC.
LANCASRER, 


\title{
DECORATIVE ART OF THE TÊTES DE BOULE OF QUEBEC
}

\author{
BY \\ D. S. DAVIDSON
}






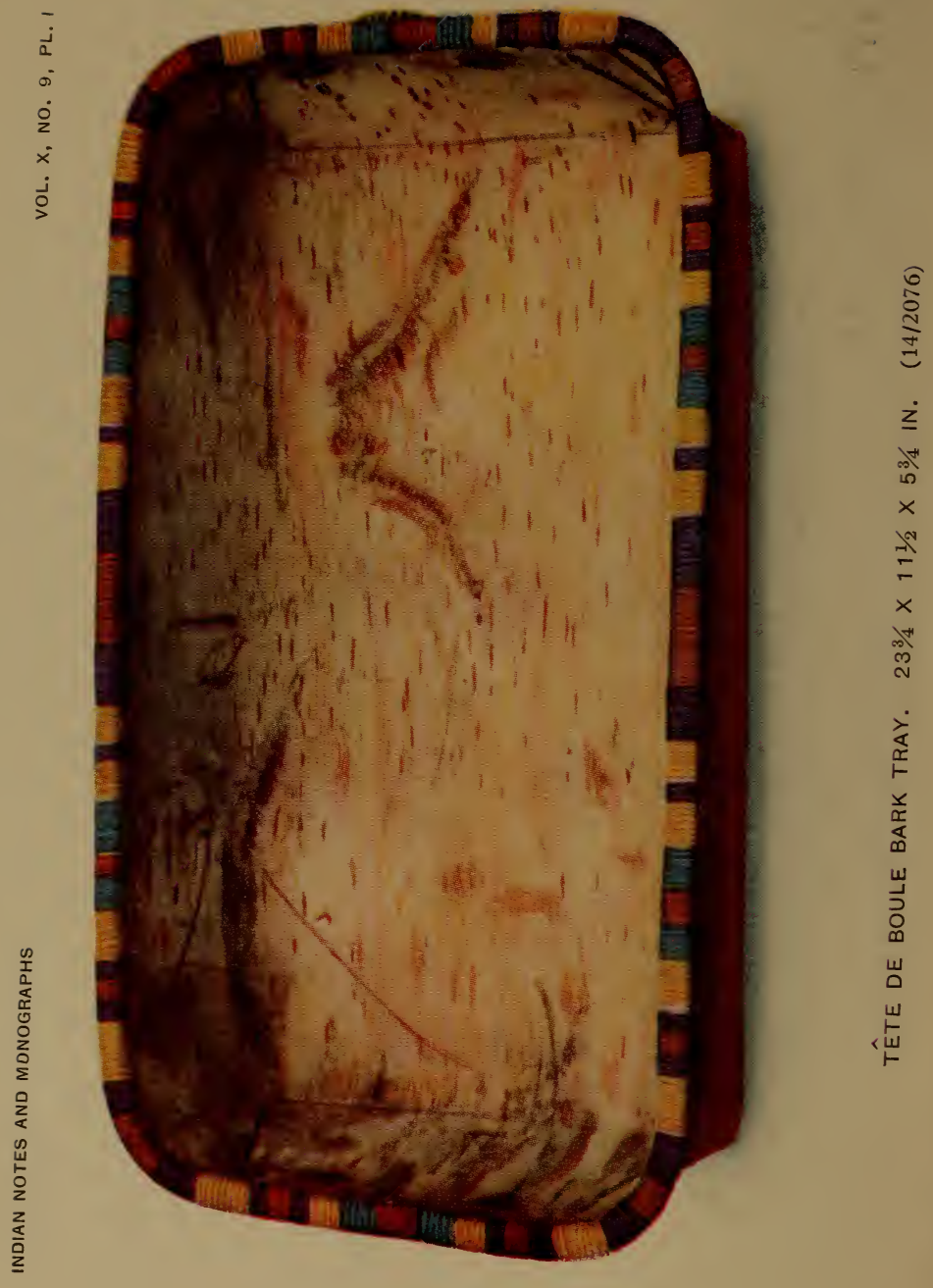




\title{
DECORATIVE ART OF THE TÊTES DE BOULE OF QUEBEC
}

\author{
D. S. Davidson
}

THE Tête de Boule Indians, who occupy the upper St. Maurice district of Quebec, are in many respects a typical band of the northeastern Algonkians. Like their neighbors they are semi-nomadic hunters, devoting most of their time to trapping operations in the bush. Although they have been known to Europeans since the early days of New France, ${ }^{1}$ their contact with civilization until recent times has never been intense; nevertheless, their reactions to the European influences which have penetrated to them have been both interesting and peculiar. In respect to culture modification, the art work of these people may be taken as a unique example.

${ }^{1}$ The Jesuits speak of the Attikamègues and of the Whitefish tribe as inhabiting the upper Three Rivers, a term which they applied to what is now the St. Maurice. The Têtes de Boule at Weymontachingue call themselves Tcekamèk' irinizwak, or whitefish people. Obviously the terms are cognates. Vide Jesuit Relations and Allied Documents, edited by Edna Kenton, pp. 161, 162, 165, 459, 460, New York, 1925. 


\section{DECORATIVEART OF THE}

\section{ACCULTURATION}

The introduction of European material culture into a native group, in those cases where native populations are not disrupted by war and disease, usually adds great zest to native artistry and ornamentation. The securing of silk threads, colored cloths, glass beads, steel needles and knives, and the other usual utensils and articles to be found in a trader's stock, in most instances produces a great art stimulation, for with these acquirements the esthetic ambition of a group may be more easily realized. The modern art work of the Iroquois, the Plains tribes, and the Labrador bands, among many others, may be pointed out as exemplifications of this stimulus. The Têtes de Boule, on the other hand, seem to have had a reaction quite dissimilar. Instead of accentuating their development in decorative art, the influence of civilization seems to have had the opposite effect, and today we find their decorative work in a very impoverished condition. Not only is their esthetic endeavor meager, but, generally speaking, their art is often executed in slovenly fashion. Of course, nothing seems to be known about the decorative art of these particular people in the past, but it would seem probable that its development was not less intense than that of their neighbors to the east where a strong art tradition is not only still retained, but in all probability is much enhanced over its former 


\section{TÊTES DE BOULE}

condition. Why this degeneration of Tête de Boule art from a supposedly higher standard has taken place will probably never be known. Apparently it is one of those unexplainable whims of preliterate culture.

\section{DECORATION OF BIRCH-BARK BOXES}

Decoration among the Têtes de Boule is confined to only two main types of articles-birch-bark containers (s., wigwàmutí, bark receptacle) and moccasins (s., maskisin). The techniques include etching in positive relief-that is, by scraping away the dark coating on the inner surface of the birchbark, leaving designs standing forth in the dark foreground with a light background. Another feature of decoration is the use of spruce-root lashings and bindings in different colors around the rims. Silk-thread embroidery and the use of braid form decorative processes on moccasin vamps. The use of glass beads seems to be unknown, ${ }^{1}$ at least it is

${ }^{1}$ Beadwork has been assigned to the Têtes de Boule by Dr. Speck in his monograph, The Double-curve Motive in Northeastern Algonkian Art, Memoir 42, Dept. of Mines, Ottawa, 1914, vide table, p. 15. There now live with the Lake St. John Montagnais several families of Têtes de Boule who are descendants of the now disrupted band of Kokokash Têtes de Boule. It is possible that this group practised beadwork, but more probable that they acquired the art since joining the Montagnais. Among the latter it is an important industry.

Porcupine quillwork may have been important in the past. The Jesuits report a headband made of this material among the Attikamègue (Jesuit Relations, vol. 32 , p. 285). 


\section{DECORATIVE AR T OF THE}

not practised at the present day, nor could any information be obtained as to its former existence. Porcupine quillwork and moose-hair embroidery are also absent. Woodcarving has been noticed on only two specimens - a small wooden ladle and a cradleboard which I was unable to obtain. The end of the

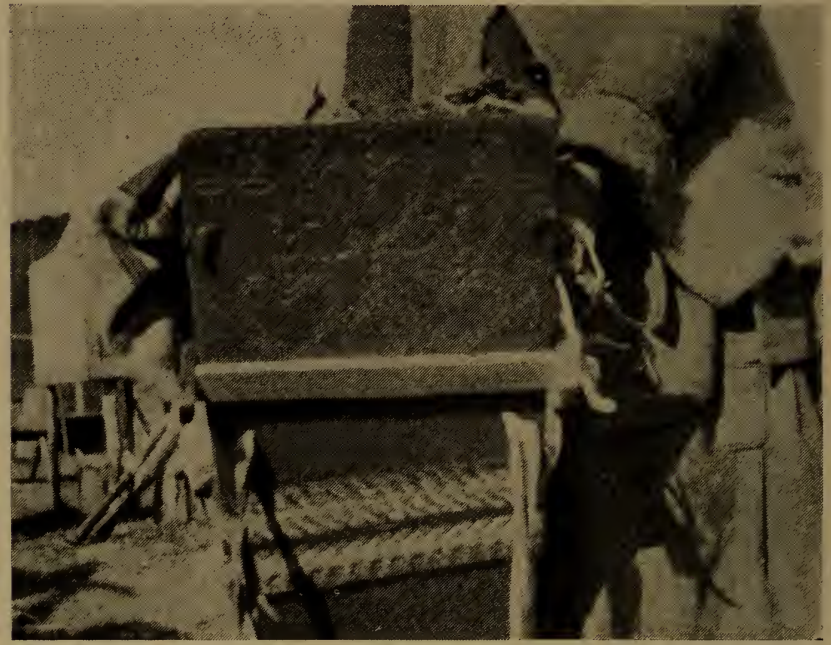

FIG. 1.-Decorated cradle-board (back view) of Manouan sub-band of Têtes de Boule.

handle of the ladle is carved into the representation of what appears to be a beaver head. All other Tête de Boule wooden ladles are undecorated, some being but crudely made. The decorations on the cradle-board are shown in figs. 1 to 4 . The heart 


\section{TÊTES DE BOULE}

may be the indirect result of Christian influence, for this design could easily have been derived from the bitten-bark patterns herein described. The

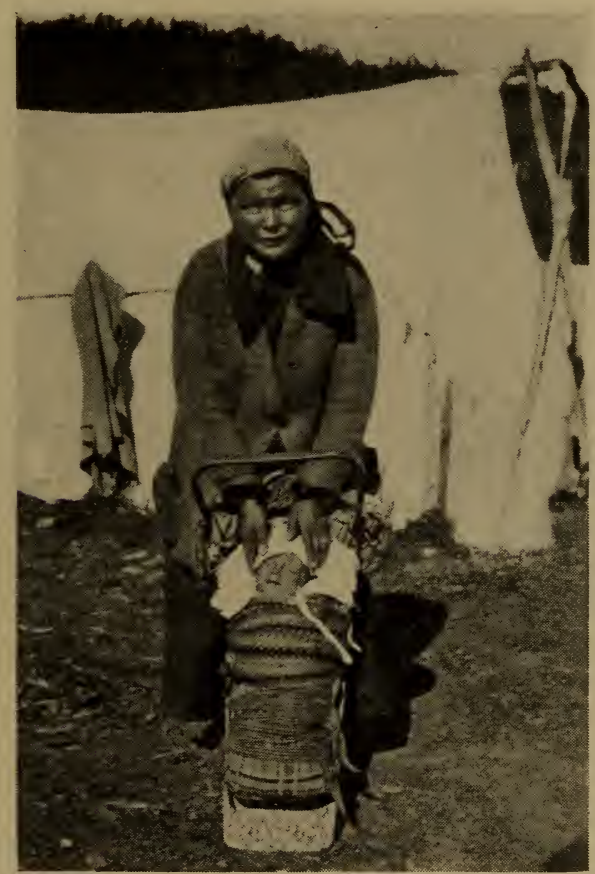

FIG. 2.-Front view of cradle-board shown in fig. 1.

dots, leaves, and triangles are consistent with the motives appearing on the birch-bark containers. Practically all of the specimens illustrated in this 


\section{DECORATIVE ART OF THE}

paper were collected by the writer during several visits to the Têtes de Boule. They are now in the collections of the Museum of the American Indian, Heye Foundation.

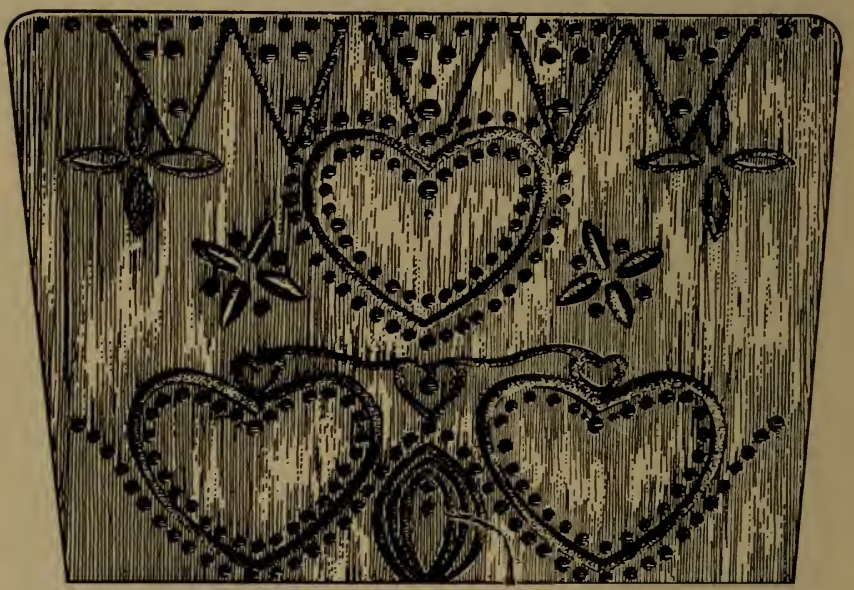

FIG. 3.-Detail of design on back of cradle-board in fig. 1.

The Têtes de Boule manufacture a great variety of birch-bark containers which range in size from small boxes of a few inches in length to large trunk-like hampers capable of holding a bushel or more. A splendid example of the latter, $20 \frac{1}{2}$ by 16 inches, is shown in fig. 5, $a$. It will be noticed that the grain of the bark runs with the length and not with the breadth as in all the other containers. The total width of this piece of bark is approximately four 


\section{TETES DE BOULE}

feet, and therefore it must have been taken from one of the largest trees of the locality. Trays are sometimes made, but seem to be rather uncommon. The one pictured in $\mathrm{pl}$. I is a fine example and of quite pretentious size, measuring $23 \frac{3}{4}$ by $11 \frac{1}{2}$ by $5 \frac{3}{4}$ inches.

One of the characteristics of Tête de Boule containers is their approximately rectangular shape.

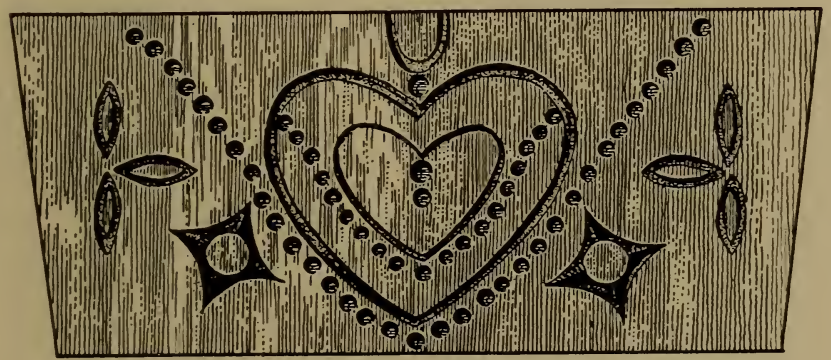

FIG. 4.-Detail of design on foot of cradle-board in fig. 1.

This feature holds true for the tops and generally for the side and end walls as well. The dimensions of the rim and cover usually do not fall far below the measurements of the bottom, and this contributes to the rectangular appearance. When the Tête de Boule objects are compared with the corresponding articles made by some of the other bands of the general region, the contrast is quite noticeable, for very often the containers of the latter have oval rims and covers, and the sides are more tapering. 


\section{D ECORATIVE ART OF THE}

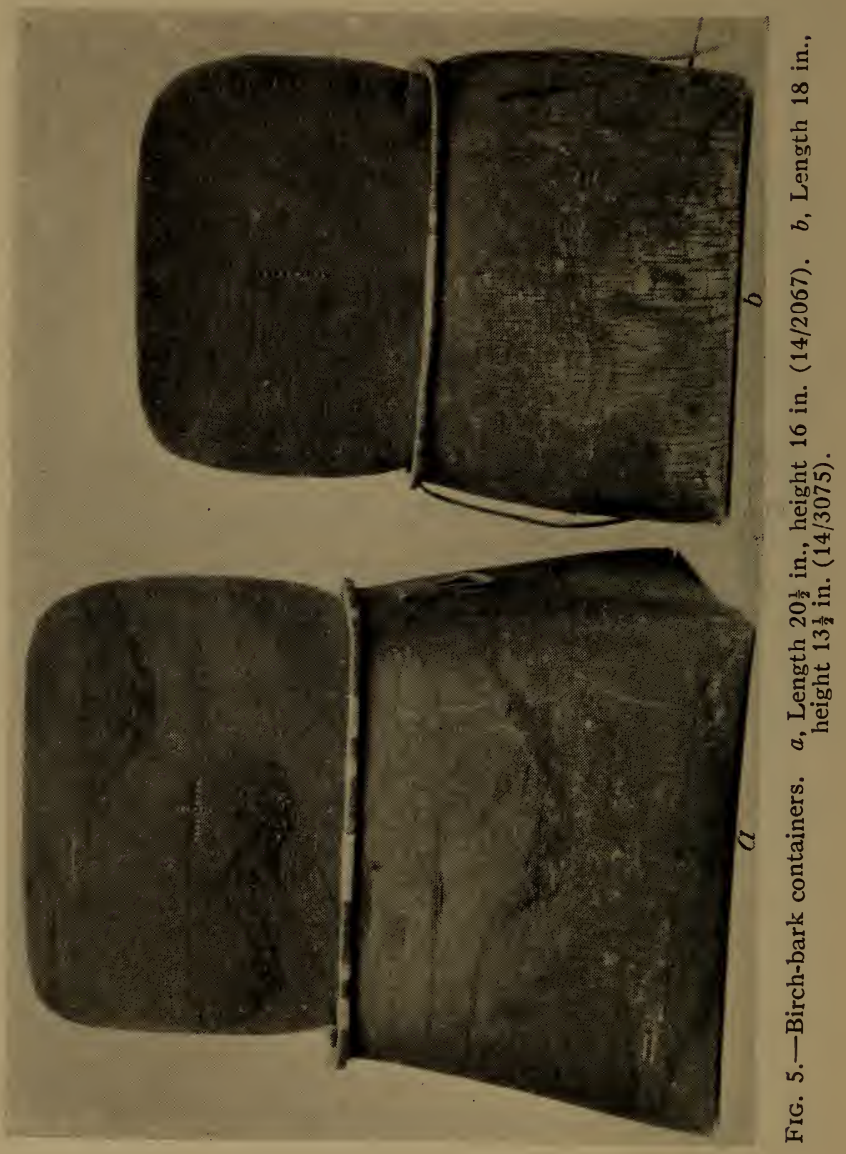




\section{TÊTES DE BOULE}

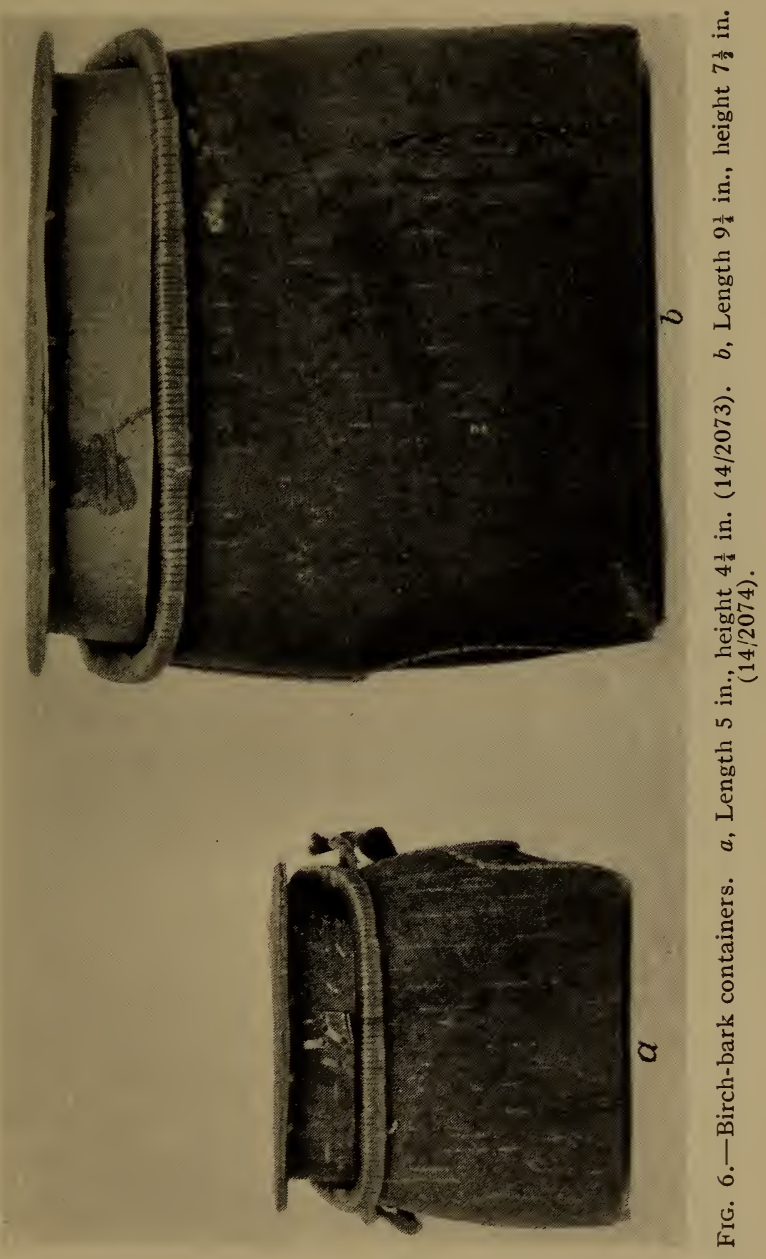




\section{D E CORATIVEART OF THE}

The side walls, in addition, are often higher in proportion to the length, and this serves to accentuate the tapering appearance.

\section{DESIGN ELEMENTS}

Very few of the Tête de Boule birch-bark boxes are decorated, those shown in figs. 5 and 6 being average examples. When designs occur on the birch-bark they are always etched in a positive style. Figs. 7 to 13 inclusive show a var ety of the design elements. It will be noticed, if one observes closely, that when a design appears repeatedly on a bark vessel, its dimensions and form in many cases seem to be identical. This condition appears to be especially striking on the wigwàmuti portrayed in fig. 10 , for here great pains were taken in the decoration. The similarity described is not the outcome of able freehand sketching on the part of each artist, but is due to the use of patterns fashioned by cutting pieces of folded birch-bark. When the bark is unfolded a double design of the original figure is formed. These patterns are then outlined on the objects to be decorated wherever the designs are desired. Figs. 7, 10, 12, and 13 well illustrate these symmetrical figures. Sometimes, however, the patterns are cut from a single thickness of bark, as for example the duck designs shown in fig. 8. It is apparent that at least two different duck patterns were used in the decoration of this vessel, the two ducks in the upper row being obviously derived from 


\section{TÊTES DE BOULE}

a different pattern from the one or ones used in the middle and lower rows. In this particular instance it is impossible to say definitely just how many patterns were used, for very often the outlining from

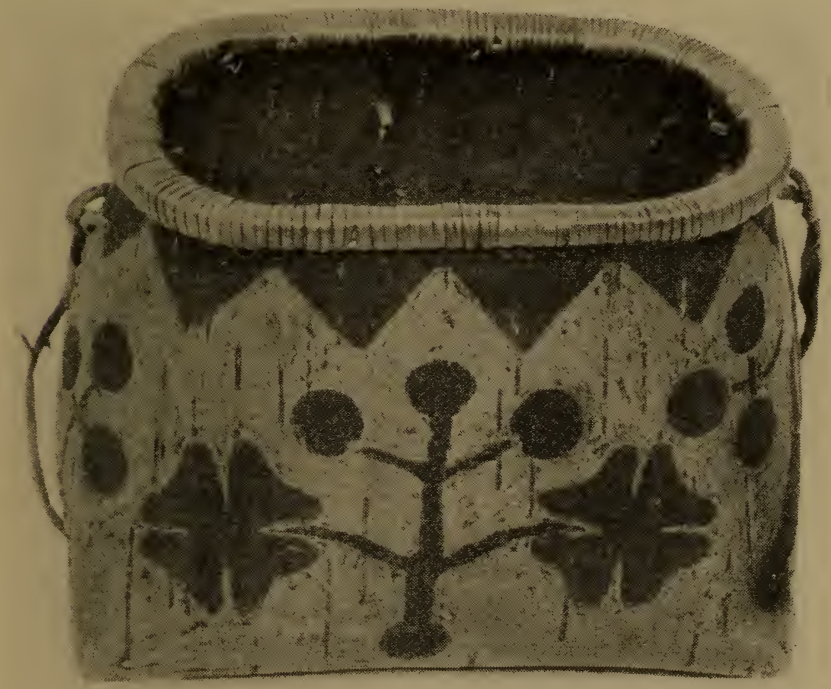

FIG. 7.-Birch-bark container. Length 6 in., height $4 \frac{3}{4}$ in.

the selected pattern is hastily or carelessly performed, and as a consequence some distortion of the original results. After the patterns have been used they are not destroyed nor thrown away, but are put aside for future use. Some are retained and used for years. 


\section{DECORATIVE ART OF THE}

If these patterns were a little more individual in style it would be possible perhaps to recognize in collections made year after year the work and decoration of various persons.

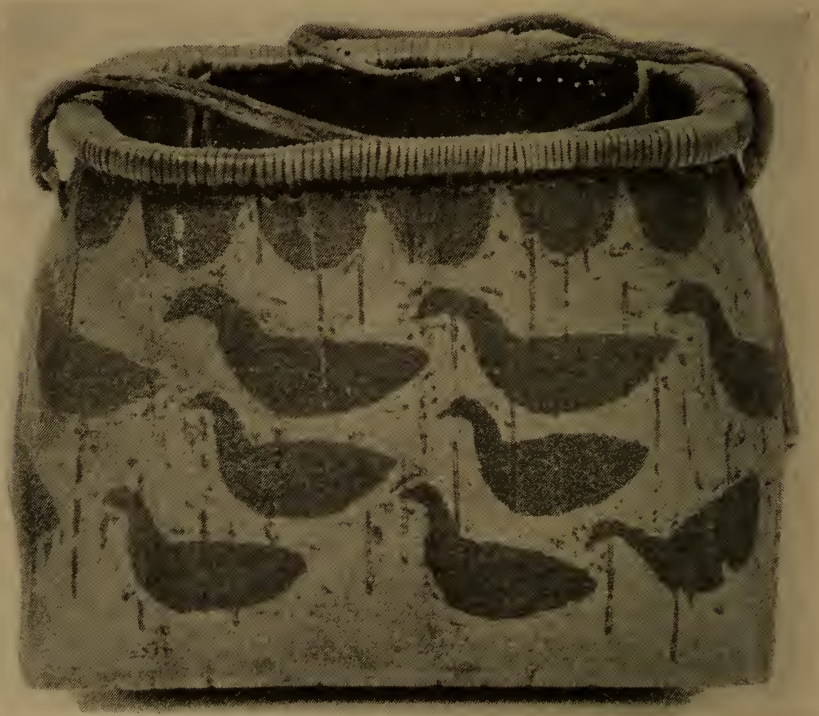

FIG. 8.-Birch-bark container. Length 6 in., height $4 \frac{3}{4}$ in. $(14 / 3080)$

After the patterns have been outlined on the places to be decorated, the surface of the bark is moistened. When it is well soaked it is possible to remove the thin dark layer with a sharp or hard instrument. The inside of the container, which is 


\section{TÊTES DE BOULE}

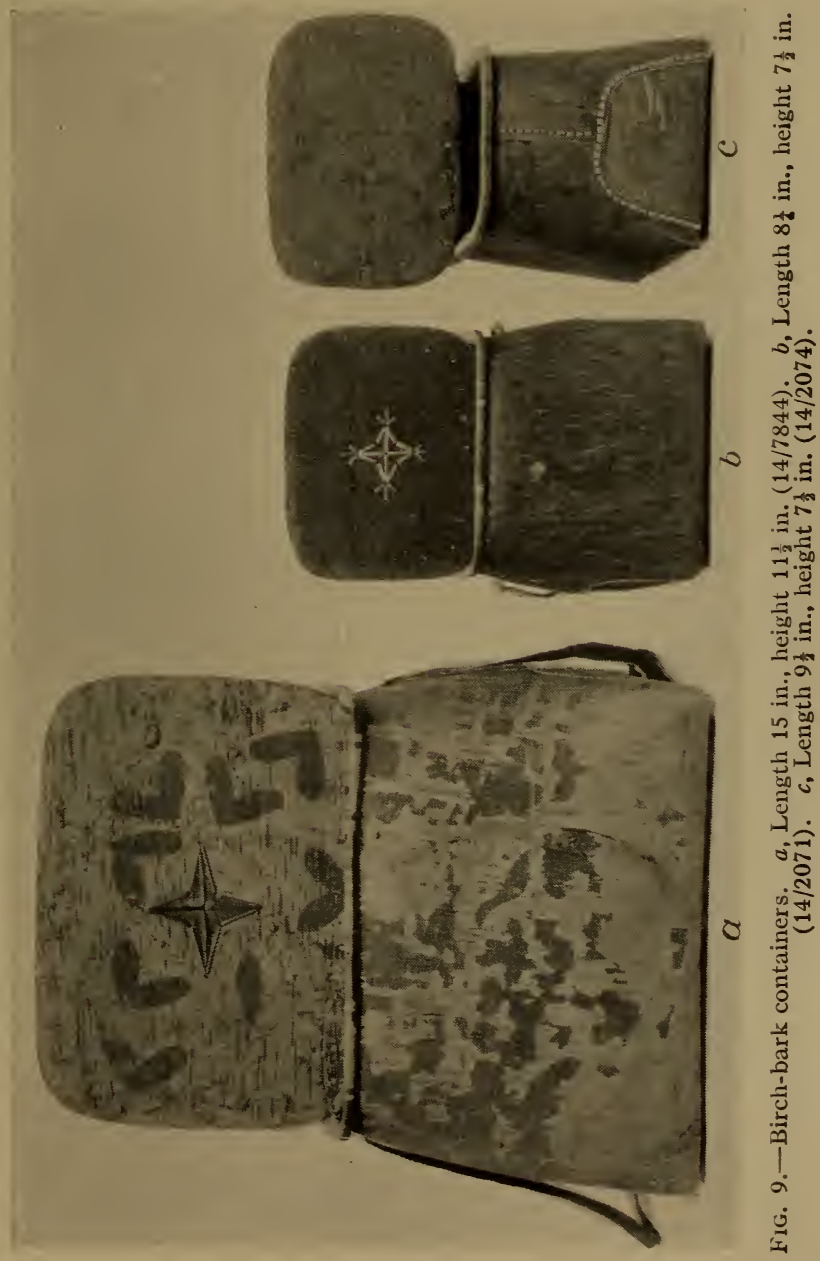




\section{D E C O RA T I VE ART OF THE}

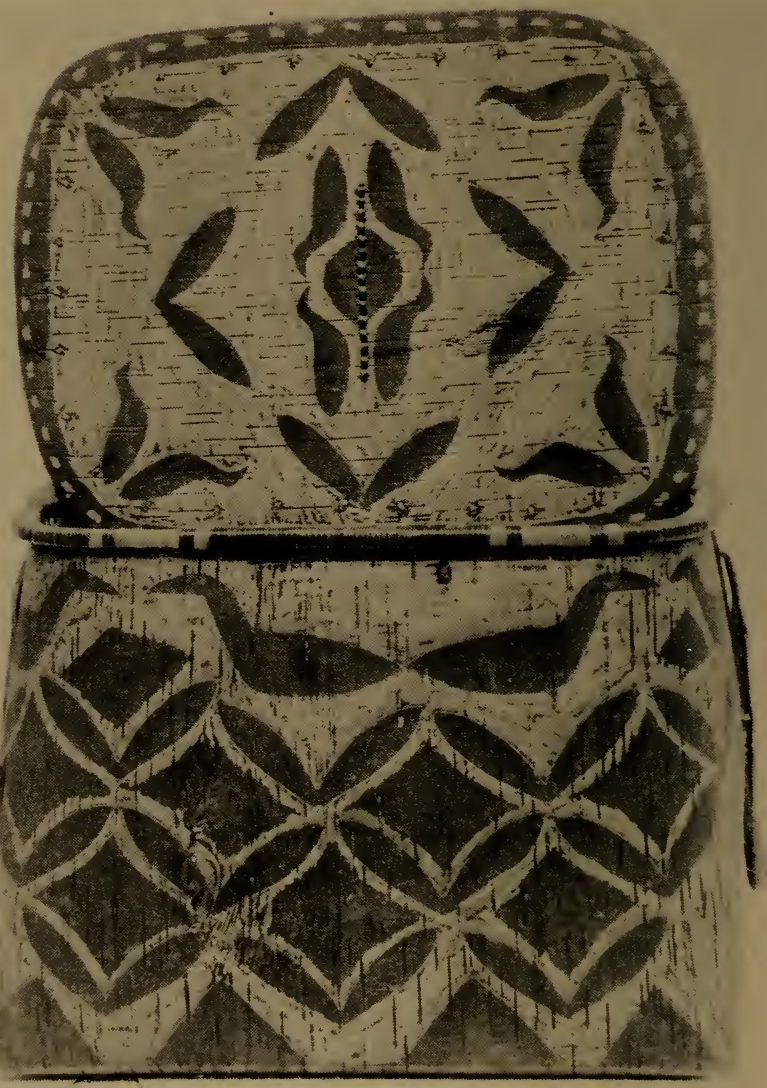

FIG. 10.-Birch-bark container. Length $15 \frac{1}{4} \mathrm{in}$., height $11 \frac{3}{4} \mathrm{in}$. $(14 / 7845)$ 


\section{TÊTES DE BOULE}

the outer surface of the bark, is never scraped nor decorated. There is no difference in use between the

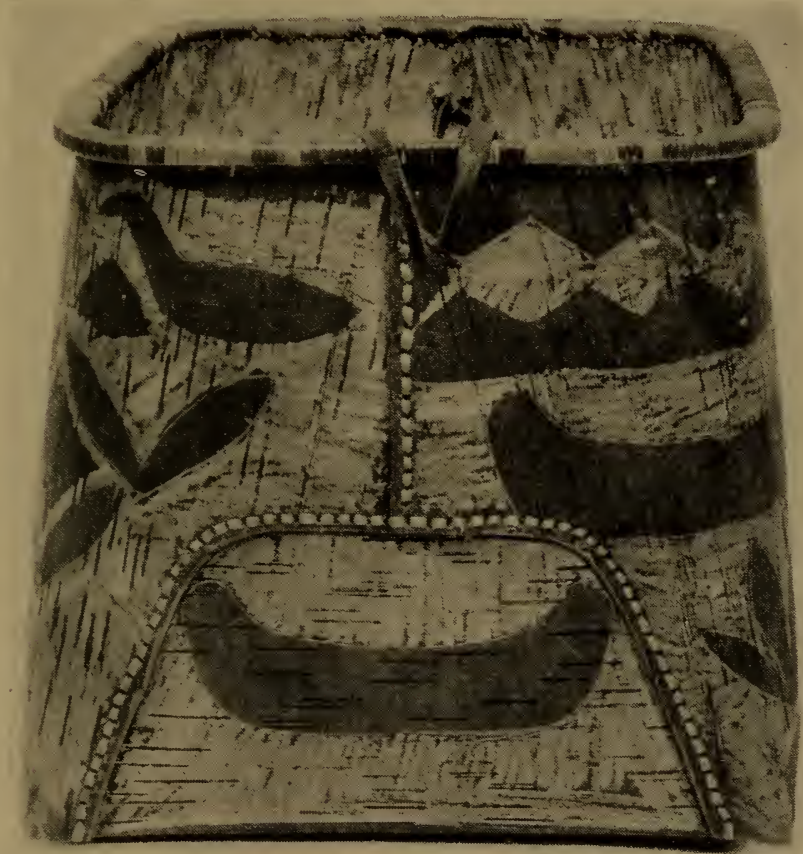

FIG. 11.-End view of the container shown in_fig. 10. (14/7845)

decorated and plain containers, for all serve utilitarian purposes. The larger ones may be used as clothes hampers, supply boxes, or as general storage 


\section{DECORATIVE ART OF THE}

receptacles. The smaller ones may serve as sewing boxes, sugar bowls, or as the keeping places for accumulated oddments.

In the decoration of the bark vessels both realistic and geometrical elements are present. It is seldom that one motive is practised to the exclusion of the other, but more often both are to be found in an inconsistent arrangement on each single decorated box. When decoration occurs, the long side walls usually receive the most attention; next in importance are the ends, and finally the cover. As will be seen in the accompanying illustrations, each wall of a decorated container has been treated independently and with complete disregard of the design elements which may have been used on the opposite side. Figs. 7 and 8 show the two sides of one wigwàmuti. Here, except for some semicircular figures around the rim, the one side is decorated almost entirely with ducks. The opposite wall, however, contains a plant figure with what appear to be flowers, fruit, or leaves, while along its rim triangular figures have been placed. There is no cover for this specimen. Fig. 9 portrays Tête de Boule decoration in its most slovenly form. The one side wall of this specimen depicts a solitary duck or loon carelessly etched in the mottled appearing surface which the artist has not taken the trouble to scrape thoroughly. At first glance the arrangement of the leaves on the cover seems to be idiotic at best, but the condition of the bark was responsible for this selection. This 
particular container was made very late in the spring when the bark cannot be worked with facility and when, consequently, decoration is quite difficult to apply. Moreover, the brown inner surface is in an

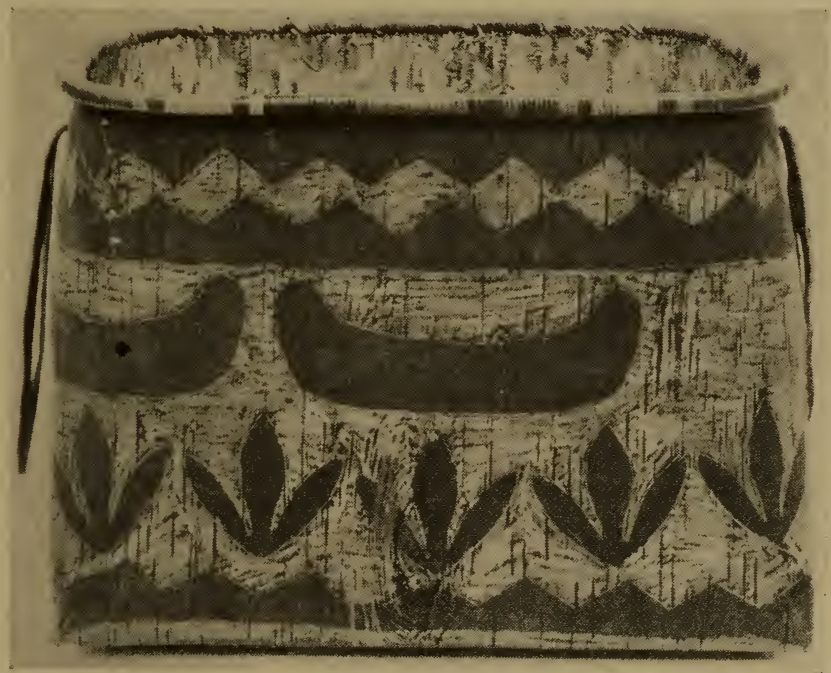

FIG. 12.-Opposite side of container shown in fig. 10. (14/7845)

especially poor condition at this period. These circumstances may excuse the artist from excellent work, but they seem to constitute a rather poor apology for such a monstrosity in decoration.

The better type of Tête de Boule endeavor in realistic decoration is shown in figs. 10 to 12 . These 


\section{DECORATIVE ART OF THE}

picture the cover, two sides, and an end of a single container. The cover is quite pleasing in appearance and the decorative elements are well arranged. The figures in the center and corners represent ducks, and the other elements were said to be leaves. The dotted arrangement around the edge represents the stitching of the two pieces of bark of which the cover is composed. Ducks, leaves, and triangles are used on one side, while canoes, leaves, and a motive which probably was intended to show diamonds but which in appearance is partly zigzag, are found on the other. The end view well illustrates the inconsistency in the decoration of the two sides.

\section{DUCK MOTIVE}

The duck motive is a common one throughout this general region, except to the east, where it seems to be unimportant although present in Montagnais ornamentation. To the south and southwest it is to be found among the Grand Lake Victoria and Lake Barrière bands, according to statements made to me by members of those bands, although I have not seen any actual specimens which portrayed this design. Farther to the southwest it occurs at Timagami, ${ }^{1}$ while to the north it has been noticed among the Waswanipi ${ }^{2}$ and Eastern Cree. ${ }^{3}$ Because

${ }^{1}$ Material collected by Dr. Speck.

${ }^{2}$ Information secured in the field which has been verified by Rev. Dr. John M. Cooper.

${ }^{3}$ Skinner, A. B., Notes on the Eastern Cree and Northern Saulteaux, Anthr. Papers Amer. Mus. Nat. Hist., vol. Ix, pt. 1, p. 46, New York, 1911. 


\section{TÊTES DE BOULE}

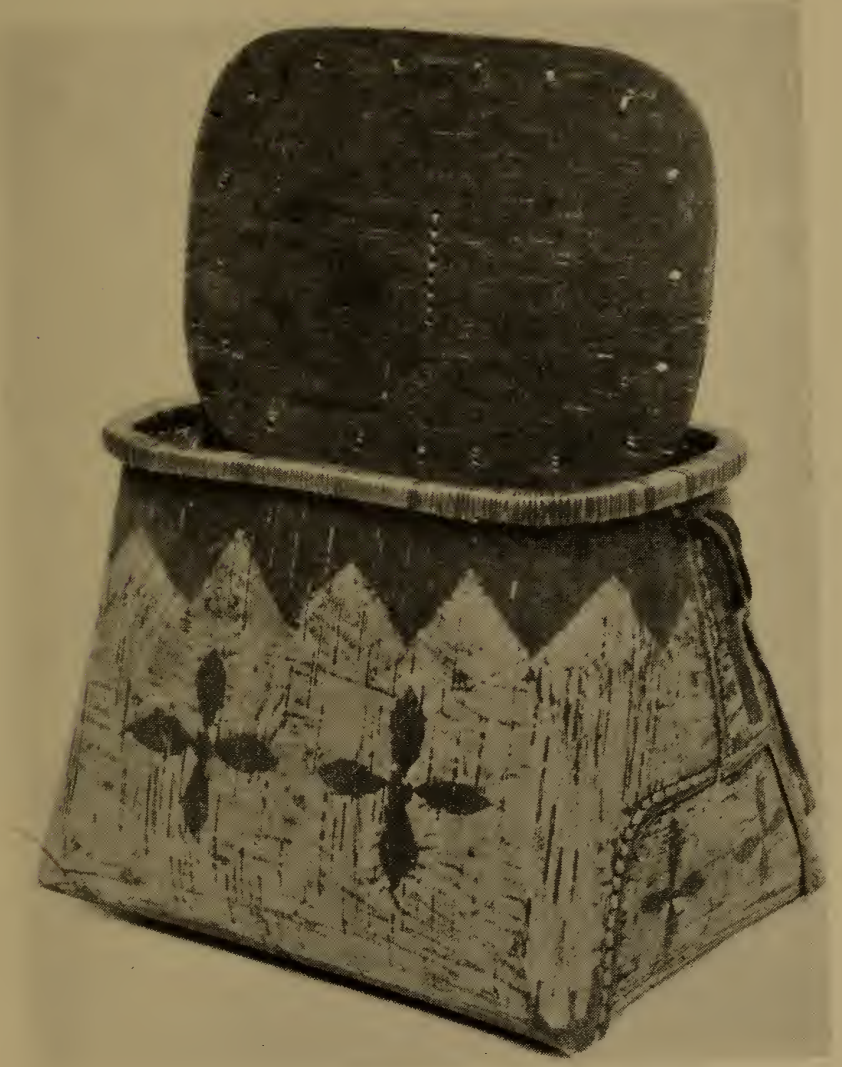

FIG. 13.-Birch-bark container. Length $9 \frac{3}{4}$ in., height $8 \frac{1}{2}$ in. (14/2075) 


\section{DECORATIVE ART OF THE}

of an insufficiency of collected material, further extension of its distribution cannot be made at this time. Among all these groups the duck motive appears to be present only on the sides and covers of birch-bark containers. There it is etched in positive relief in the manner described. The Hudson Bay, Ungava, and Labrador Eskimo should be included perhaps within this area of distribution, for the duck seems to be a common subject among their sculptured ivory work. ${ }^{1}$

The place of origin of the two containers shown in figs. 14 to 17 cannot be definitely asserted, although both seem to have come from the region of Obidjuan. Neither, however, was secured directly from the Indians. One was obtained by Dr. Speck at Weymont from Mr. Delair who had picked it up at Obidjuan; the other was procured by the writer from Mr. Edwardson at Oscalaneo. Neither Mr. Delair nor Mr. Edwardson remembered from whom the respective containers had been obtained. Since Indians from Waswanipi go to Obidjuan and Oscalaneo each summer, there is a possibility that both may have been derived from that source. Both are decorated in a similar geometrical style, dots, lines, and zigzags predominating. The cover of one (fig. 16) is also well ornamented with the

${ }^{1}$ Turner, L. M., Ethnology of the Ungava District, Hudson Bay Territory, 11th Ann. Rep. Bur. Amer Ethnol., p. 260, Washington, 1894; Hawkes, E. W., The Labrador Eskimo, Memoir 91, Geol. Surv., pl. 32, Ottawa, 1916. 


\section{TÊTES DE BOULE}

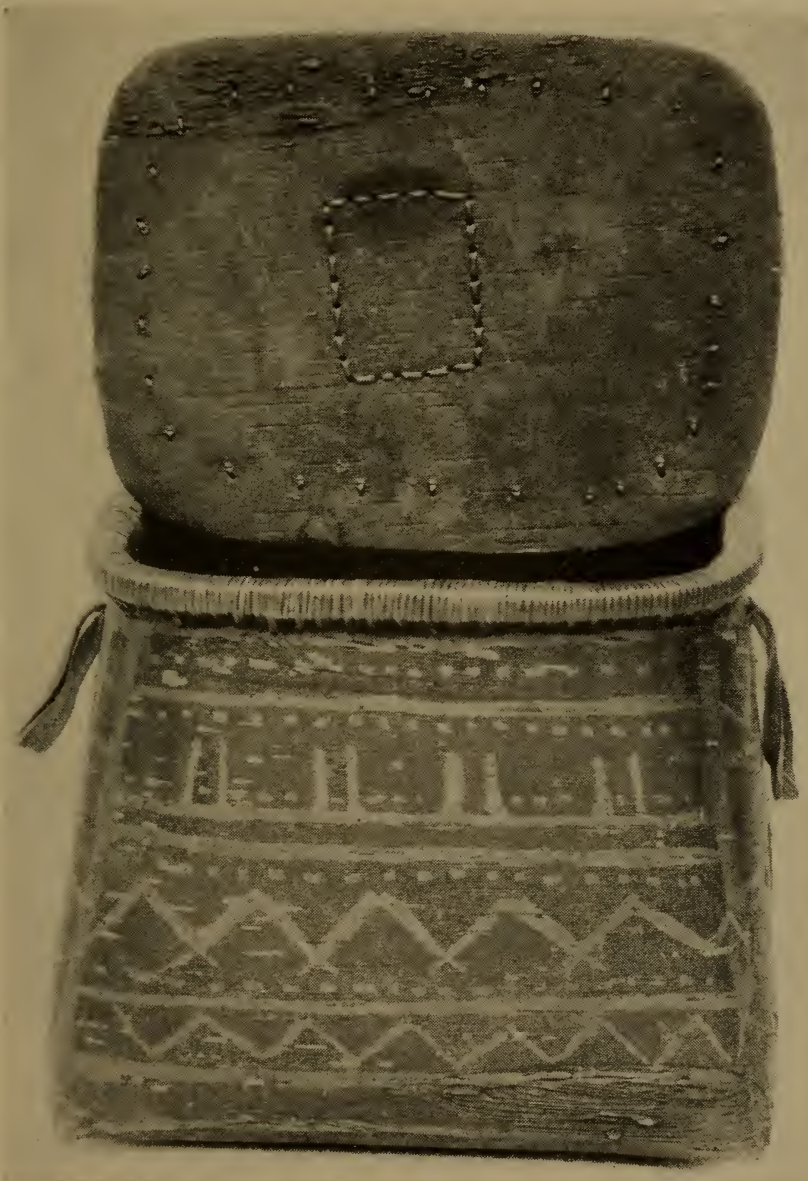

FIG. 14.-Birch-bark container of undetermined origin. Length $10 \mathrm{in.,}$ height 9 in. $(13 / 7002)$ 


\section{D E CORATIVE A R T OF THE}

stitch design. This container does not have the end flaps cut out like the others, and in addition these flaps are sewed to the container at the bottom as well as in the usual semicircular fashion. It must

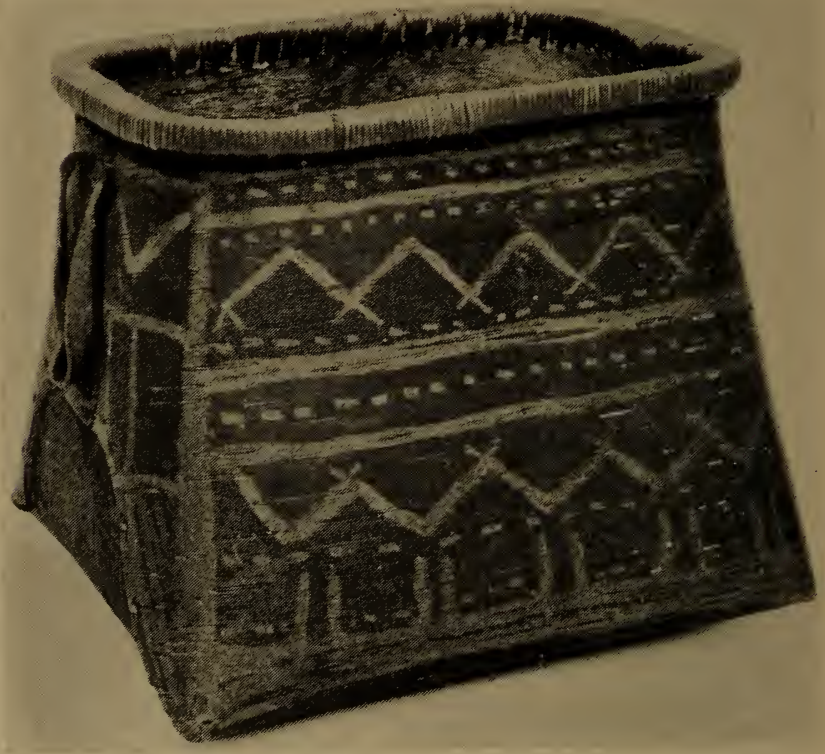

FIG. 15.-Opposite side of the container shown in fig. $14 . \quad$ (13/7002)

also be pointed out that on both of these boxes the stitching is widely separated, and this is in distinct contrast to that noticeable on the average bona fide Tête de Boule container. Questioning of the Têtes 


\section{TÊTES DE BOULE}

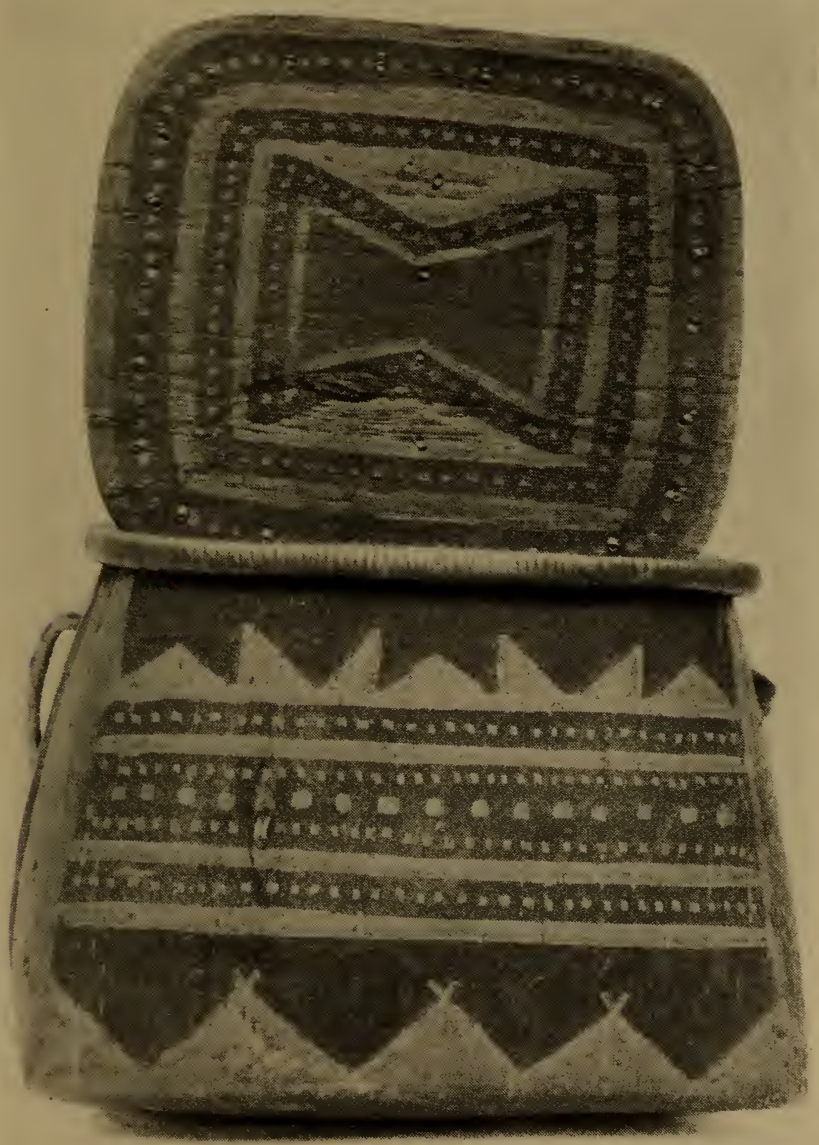

FIG. 16.-Birch-bark container of undetermined origin. Length $8 \frac{1}{4}$ in., height $6 \frac{3}{4}$ in. $(14 / 3094)$ 


\section{D ECORATIVE A R T OF THE}

de Boule themselves did not elucidate the matter. At the present time very little is known about the decorative art of the Waswanipi, hence until material

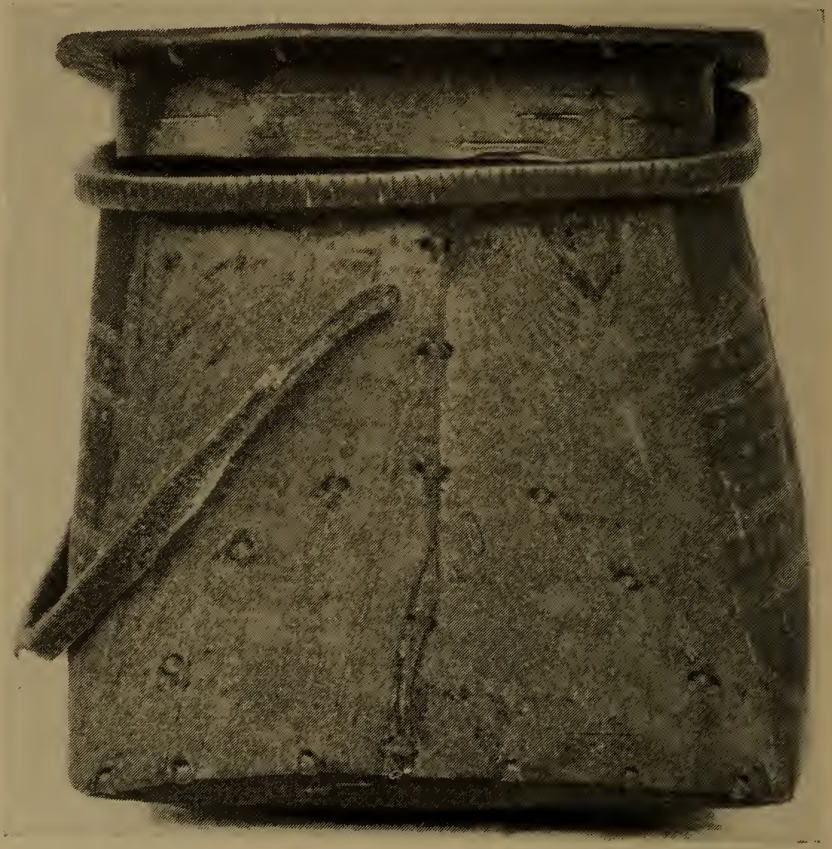

FIG. 17.-Opposite side of container shown in fig. 16. (14/3094)

is forthcoming from them it seems allowable to maintain an attitude of skepticism on this point. The covers of the containers are generally without 
decoration. The ones shown in figs. 9, 10, and 16 do not represent those ordinarily found. Practically every cover, however, except the very small ones, shows some stitching in the center, and this often assumes an artistic form. The incentive to decorate the centers of the covers is strictly the result of a utilitarian need, for, as the covers consist of two layers of bark, some stitching is needed to prevent bulging. Figs. 5, 10, 13, and 14 illustrate the usual method of joining the two layers. The esthetic possibilities which this feature may attain may be seen in fig. 9, $a, b$. Another cover feature is the stitch design which often appears around the edge and which has already been mentioned.

\section{Rim Decoration}

The rim of a wigwàmutí is composed of a rim proper made of wood and spruce-root lashings (otabi) which fasten it to the container. These lashings are wound around the wood in continuous fashion and in such manner that each loop is passed through a small hole awled in the bark vessel and then is wound upward and over the rim again. The lashings are placed close together, so that each loop touches the parallel loops on each side of it. Very of ten two loops are passed through the same hole in order to conserve the strength of the bark, for if a hole were made for every loop, fraying of the bark might occur. At the rounded "corners" sometimes as many as three loops are passed through the same 


\section{DECORATIVE A R T OF THE}

hole. In these cases there is an additional incentive, for in order to retain the regular interval of the lashings along the outer and consequently longer ledge, and on the top, the shorter inner margin requires that an overlapping be made. The desired result of external appearance is thus secured through this method of wrapping.

The roots are rarely retained in their natural hue, but are generally dyed in varying shades of the primary colors, hence a fine opportunity for a decorative scheme presents itself. Differently colored roots are wrapped around the rim in blocks at intervals which vary according to the ideas of the maker. Each block is contiguous to the next; that is, there is no break in the continuous wrapping around the rim. Usually the middles of the four sides are wrapped in the same color. Proceeding from the middles in both directions the contiguous colors are identical; likewise the third colors are respectively the same, and so on until the corners are met. In pl. I the large tray well illustrates this decorative principle. The arrangement of the lashings may also be noticed in the pictures of the other bark objects.

In some cases the color scheme may run in a sequence such as white, red, green, white, red, green, this order being followed around the complete rim. While there may be a few cases in which the rim decoration may be irregular, it must be emphasized that in respect to the use of colored lashings the 


\section{TÊTES DE BOULE}

Tête de Boule containers appear to be entirely consistent. Of the scores which the writer has collected or examined in the field, not one has been seen which did not correspond in this feature.

The distribution of this particular style of rim decoration is a problem which has never received the serious attention of anyone. To the south of the Têtes de Boule it seems to be lacking entirely. The Lake St. John Montagnais to the east use it but little, according to Dr. Speck; but among the Mistassini to the north it is very common, if not characteristic. The Grand Lake Victoria and Lake Barrière bands to the southwest, according to verbal information as well as by an examination of a few specimens, seem not to practise this decorative scheme. The rims of their birch-bark vessels are characterized by wrappings in the plain undyed color of the roots, and they are therefore unattended by any arrangement of an esthetic nature. In this respect they agree with their southwestern neighbors, the Timagami and Timiskaming. Farther to the southwest are the Ojibwa, who likewise seem to lack the colored rim element. Among the Athabascans however, the use of colored rim lashings seems to be well known and practised over a wide area. Specimens from many places which are in the Museum of the American Indian, the University Museum at Philadelphia, and the McGill Museum of Montreal, show many examples of this nature, although the styles of manufacture of the containers 


\section{D E C O R T I V A R T OF THE}

themselves are quite different. For the regions intermediate to those mentioned nothing may be said until the necessary material has been collected from the field.

\section{Moccasin Decoration}

Aside from the birch-bark containers, the moccasin is the only other article of the Têtes de Boule which receives much decoration. Moccasins are of three main types, as shown in figs. 18 and 19 . Of these three the ordinary puckered moccasin constitutes at least ninety percent of the moccasins manufactured. The Weymontachingue Têtes de Boule produce annually hundreds of pairs of moccasins which they sell to the Hudson's Bay Company. These are shipped to other posts where they are sold to the Indians whose region has become devoid of moose and caribou, and where consequently there now exists little material for the manufacture of this type of footwear. At Weymont, therefore, I found it possible to examine a multitude of new and unworn moccasins in addition to those worn by the natives themselves. There are no differences between those manufactured for export and those made for home use.

The ordinary puckered moccasin is usually plain except for a line or two of silk braid which may be sewed around the margin of the vamp (fig. 18,a). In some cases even this feature has been dispensed with. In a few pairs I found this type of decoration 

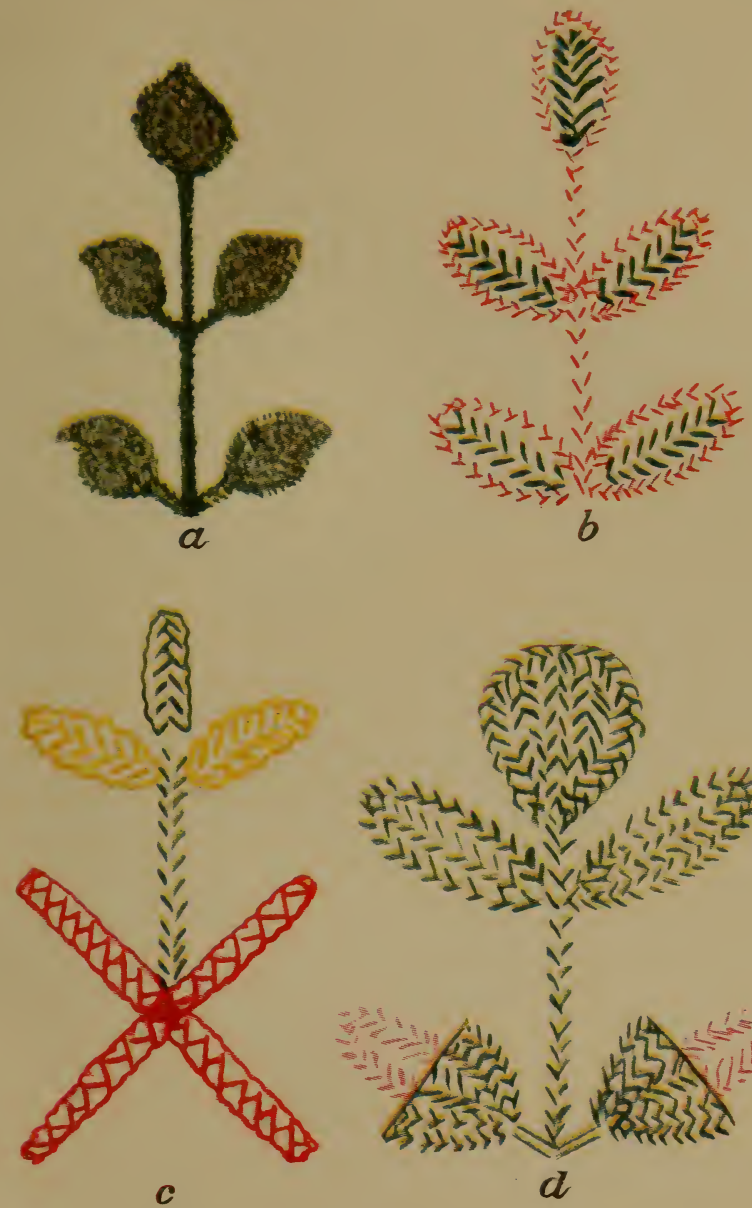

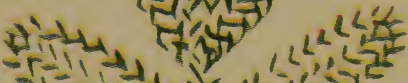
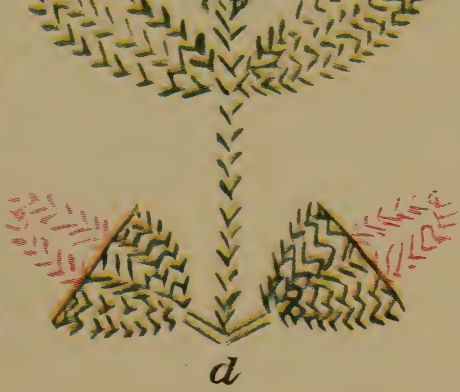

MOCCASIN VAMP DESIGNS OF COARSE TYPE 



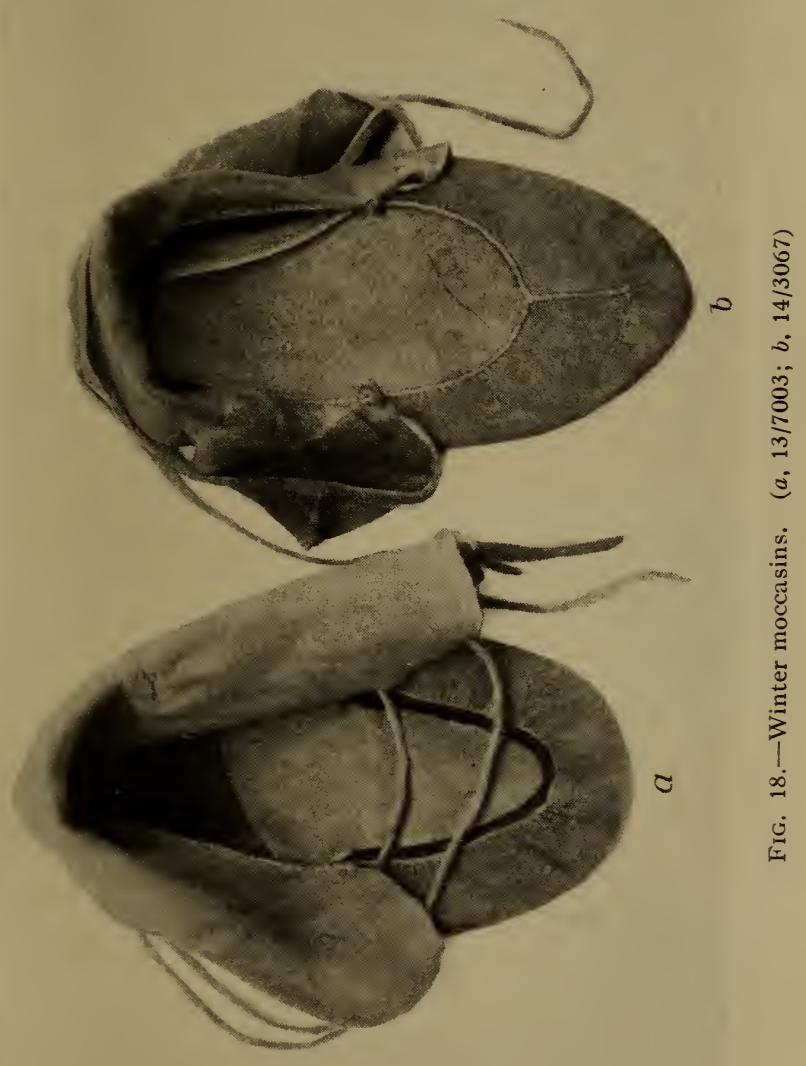




\section{DECORATIVE A R T OF THE}

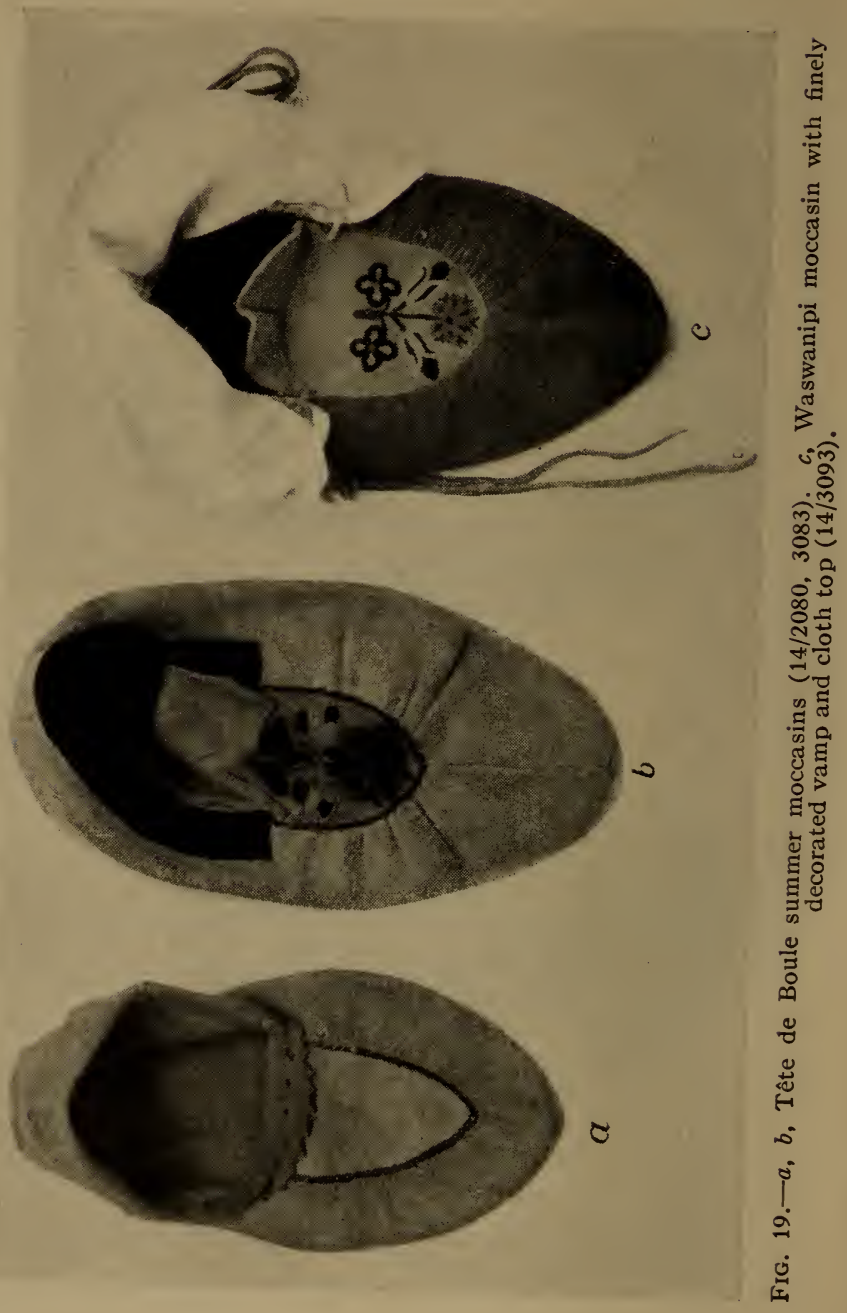



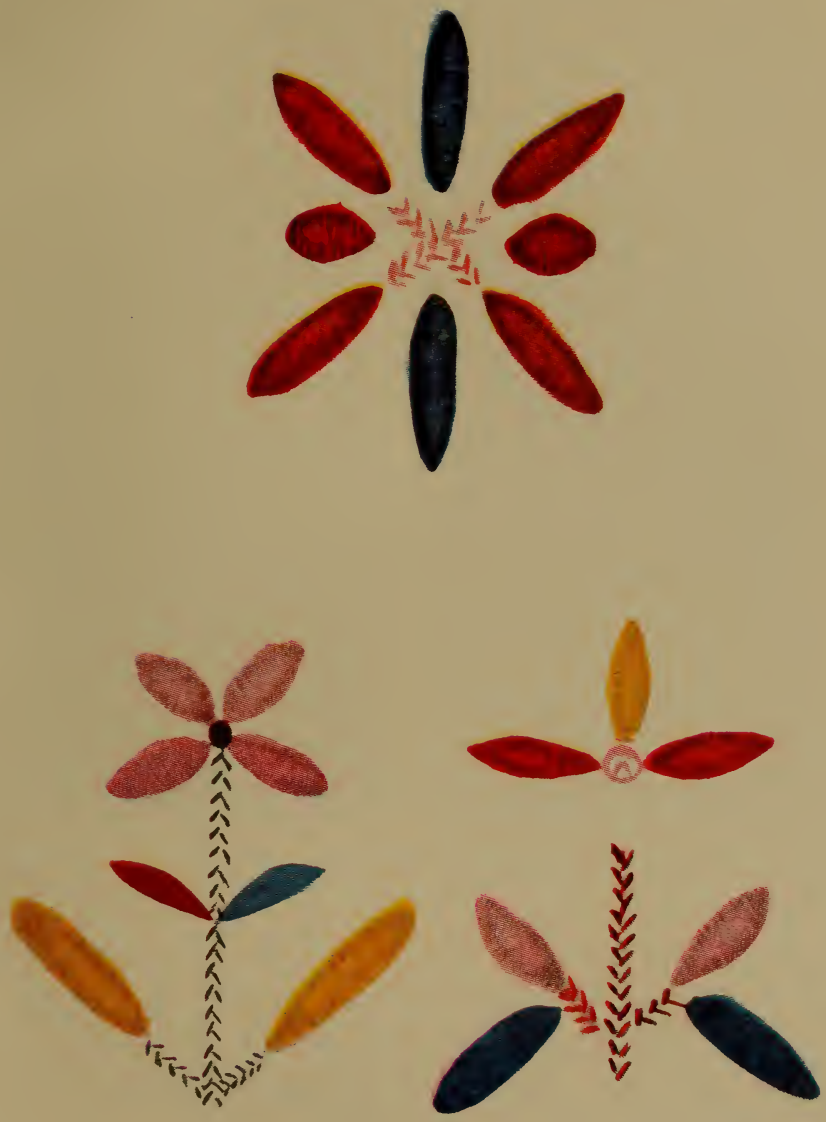

MOCCASIN VAMP DESIGNS OF INTERMEDIATE TYPE 



\section{TÊTES DE BOULE}

to consist of silk thread. Various types of stitching were used, according to the will of the maker. Some of these may be distinguished in fig. 19, $a-c$. There seems to be no general symbolic significance

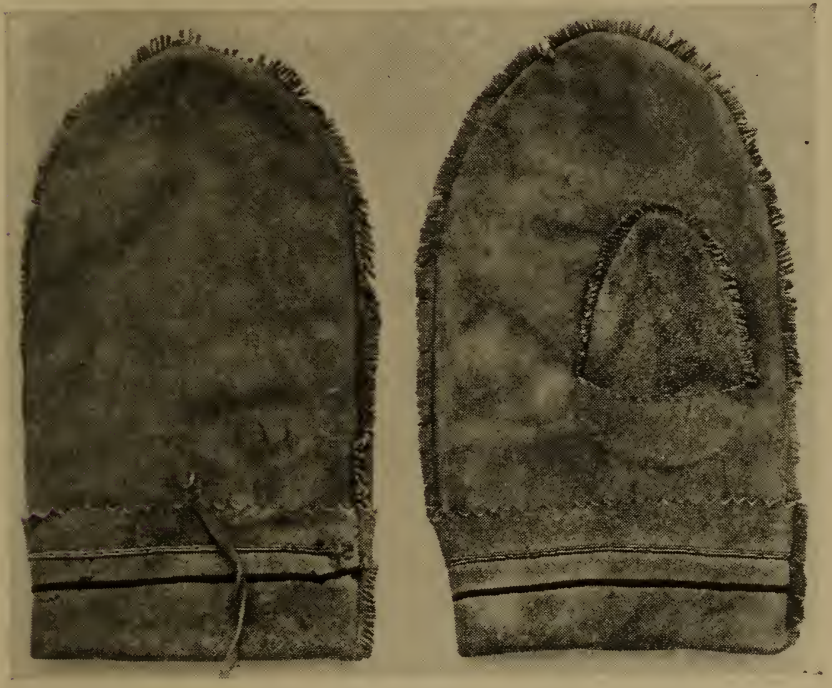

FIG. 20.-Mittens with braid decoration. (13/7006)

for this type of decoration, although one old woman told me that the single line represented a river and that a zigzag line implied rapids. This interpretation seemed to be entirely her own, for I could find no substantiation for it among the other women. The use of a line or two of silk braid for decorative 


\section{D ECORATIVE AR T OF THE}

purposes is not confined entirely to moccasins, but may also be applied to the cuffs of mittens (fig. 20), bags, and other leather articles. The rim of the moccasin is often improved in appearance by the addition of tape or a strip of cloth as in fig. $19, b$.
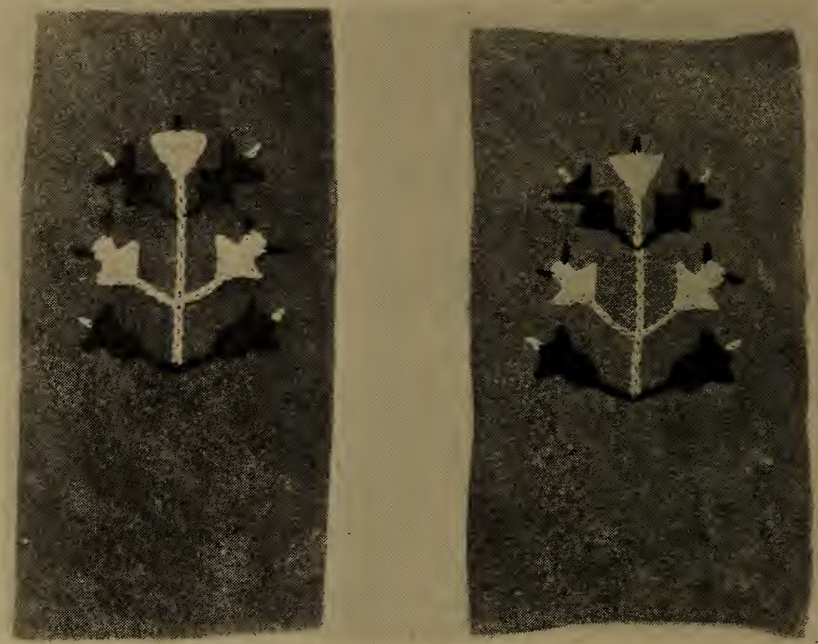

FIG. 21.-Moccasin vamps decorated before cutting and joining to the soles. The dark denotes red, the light indicates blue. (14/3084)

This feature is to be found even on some winter moccasins, in spite of the added uppers.

A great many moccasins, although their proportion of the total is not large, have floral designs sewn on the vamps. These range in quality of workmanship from carelessly made coarse stitching in silk thread 


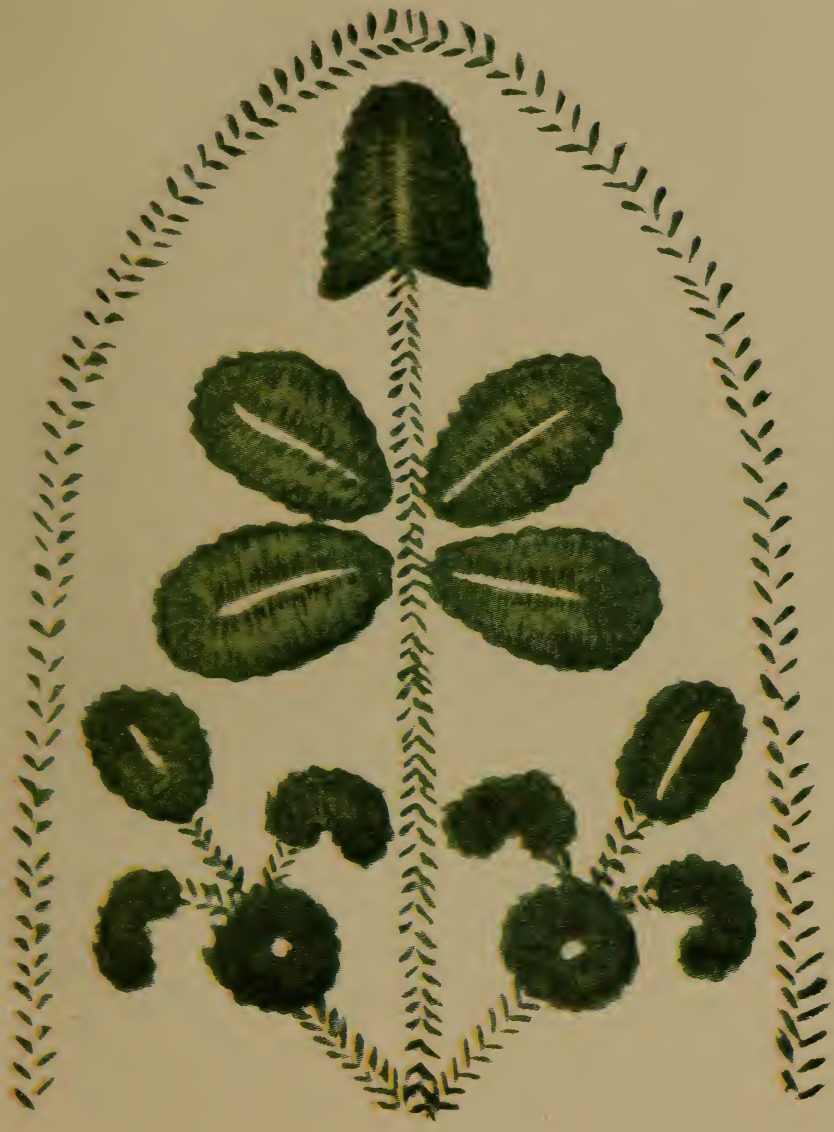

MOCCASIN VAMP DESIGN OF FINE TYPE BUT OF A SINGLE COLOR 



\section{TÊTES DE BOULE}

147

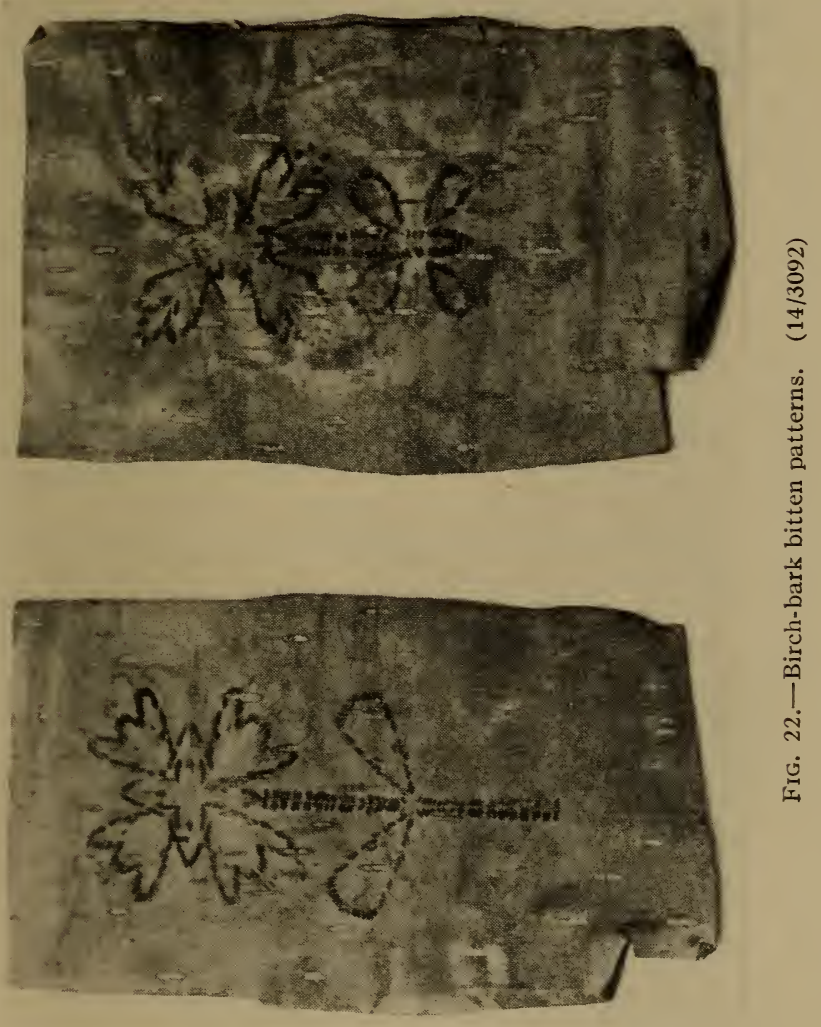




\section{D E CORAT IVE A R T OF THE}

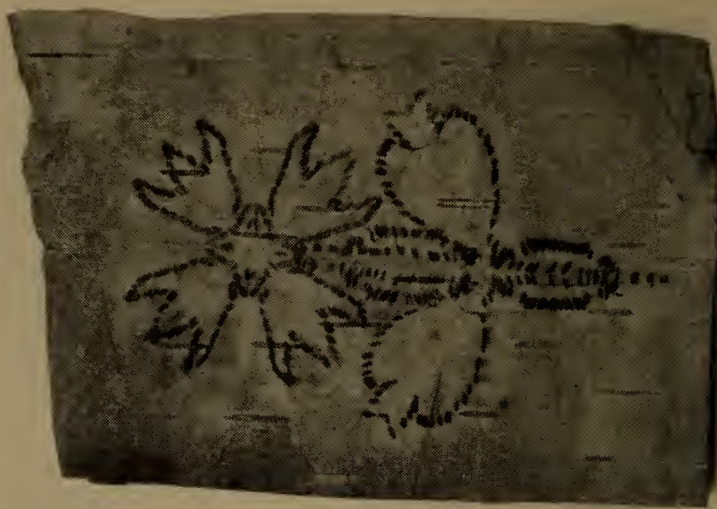

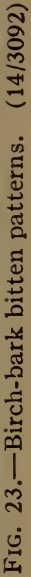

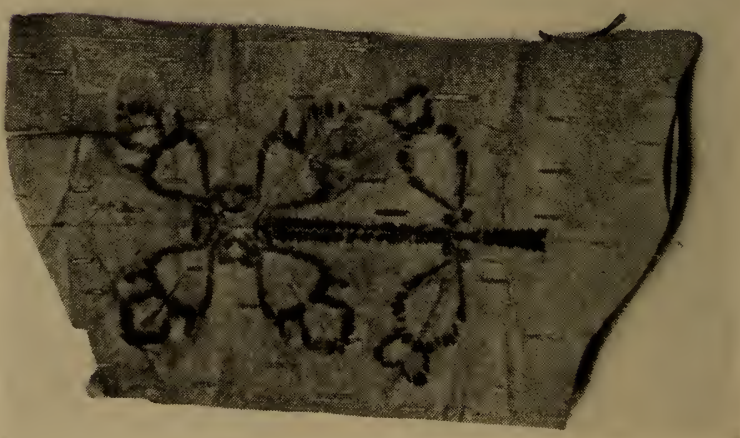




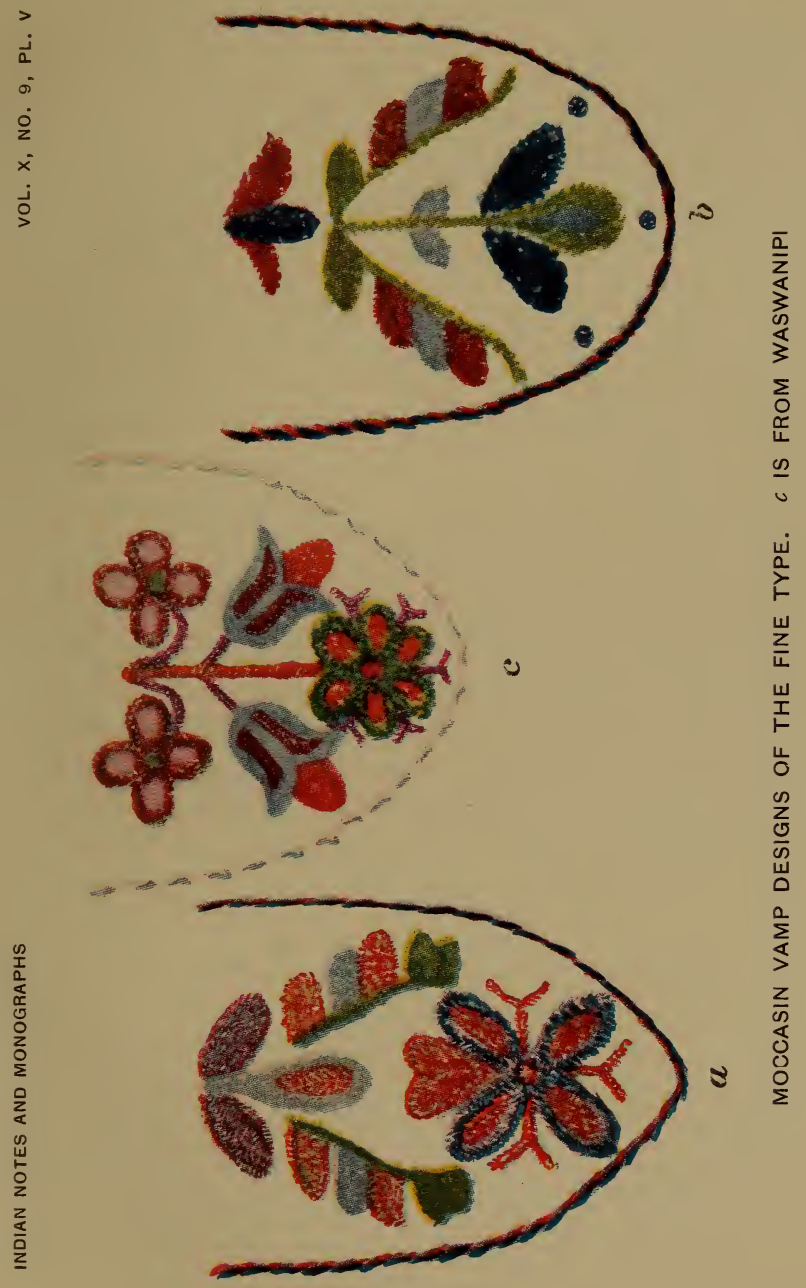





\section{TÊTES DE BOULE}

of one color to finely executed designs in which threads of many colors are utilized. Pl. II illustrates the former type, and $\mathrm{pl} . \mathrm{v}, c$, portrays the latter. The latter is from Waswanipi and surpasses in quality all of the Tête de Boule specimens which the writer has seen. A few approach it in fineness of detail. The designs are sewn to the vamps before the latter are attached to the body of the moccasin (fig. 21) and are sewn in the blind-stitch fashion, most of the stitches not passing through the thickness of the leather.

\section{BITTEN-BARK PATTERNS}

It will be noticed that the floral designs are all more or less similar in general character. Individually the right and left halves are always identical. This matter of symmetry is dictated by the method of selecting the designs used. This method consists of biting patterns in birch-bark. A rectangular piece of bark of about $3 \frac{1}{2}$ by 5 inches is peeled until a layer of the desired thinness is obtained. ${ }^{1}$ This

${ }^{1}$ Kohl, J. G., Kitchi Gami, p. 412, London, 1860, speaks of birch-bark biting among the Ojibbeways. "This is an art which the squaws chiefly practice in spring in their sugar plantations. Still they do not all understand it, and only a few are really talented." Kohl proceeds to tell of the selection of the bark and how it was doubled and thrust between the teeth. In reference to the biting, he remarks, "The bark is not bitten into holes, but only pressed with the teeth, so that, when the designs are held up, they resemble to some extent those pretty porcelain transparencies made as light-screens." 


\section{D ECORA T I E A R T F T H E}
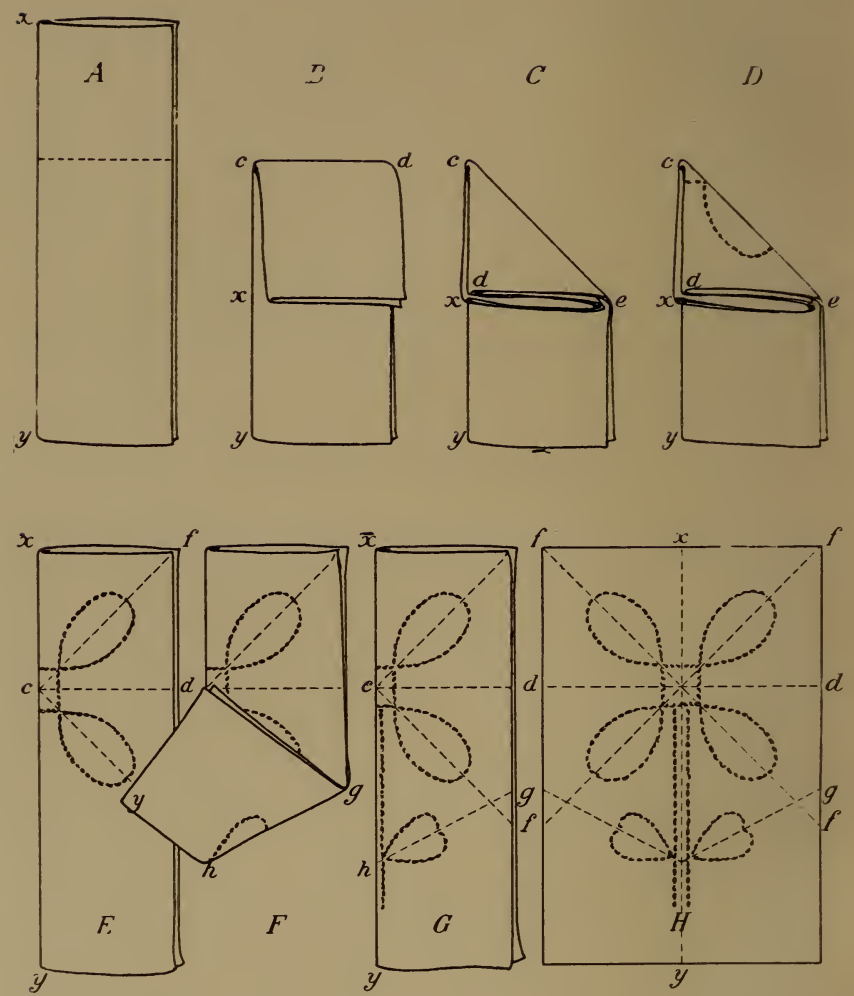

FIG. 24.- Showing the method of folding and biting birch-bark to produce moccasin designs. 


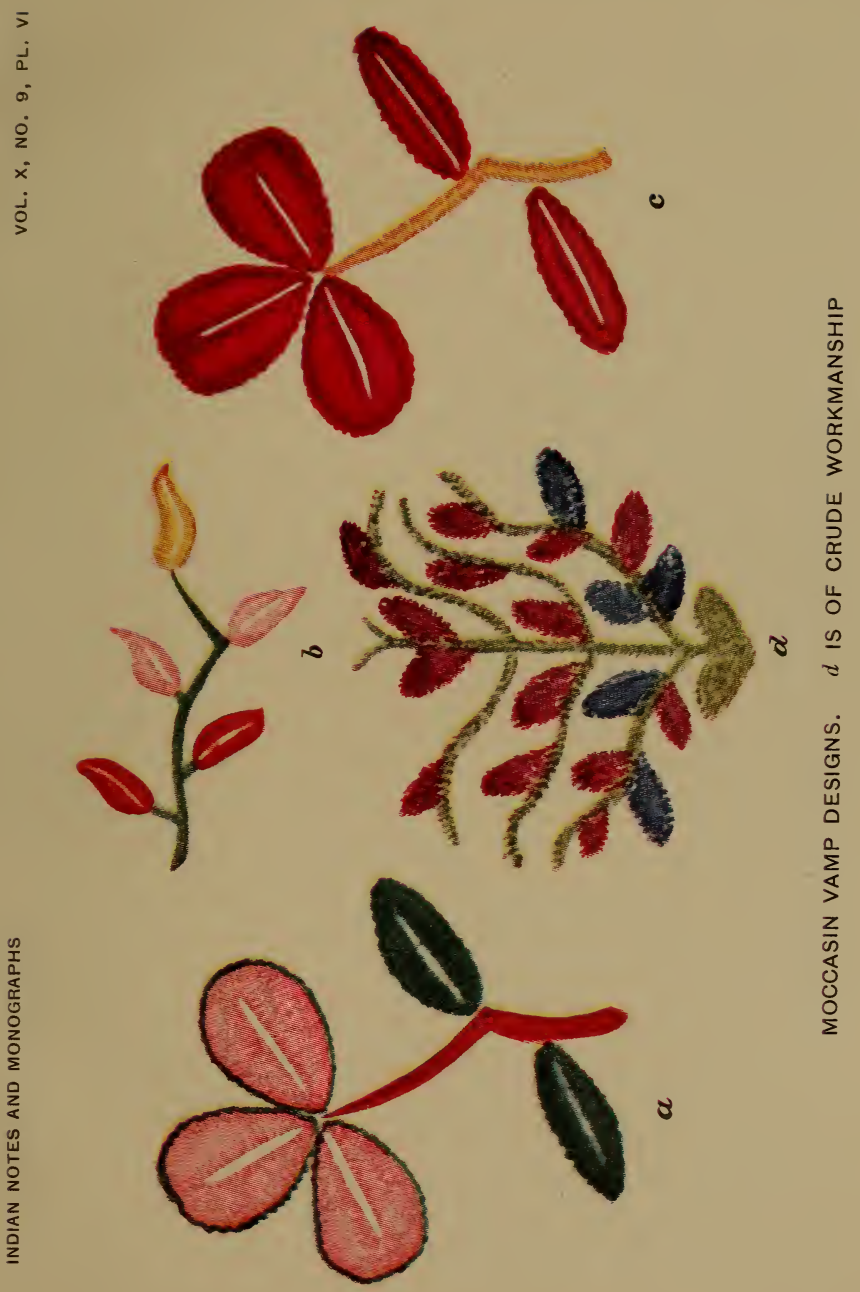



piece is then folded double, the fold running with the grain, as indicated in fig. 24. The upper third, $c-x$, is next folded down as shown, the fold $c-d$ being at right angles to $c-x$. Lastly, a fold is made along the axis $c-e$, obliquely to $x-y$, the corner $d$ being brought over and superimposed along the line $c-y$. As will be noticed, the section $c-d-e$ is composed of eight thicknesses of bark, each triangle being of $45^{\circ}$. While held in this shape the bark is inserted between the teeth and impressions are made along the line $c-e$ and across the angle $d-c-e$. It should be pointed out that these teeth-marks are made in a curve and in such manner that both ends of the curve intercept the axis $c-e$, for in order to have the bitten pattern contiguous from one thickness to the next when the pattern is unfolded, it is necessary that the bitten curve touch the axis common to them both.

The bark is unfolded until only the main fold $x-y$ is retained. The lower third then undergoes a similar process, but in this case only one additional fold is made and this usually at an angle of about $120^{\circ}$ with $x-y$. Four thicknesses result, and these are bitten along the axis $h-g$. The original fold is then returned to and the design in the upper part is joined to the lower one by biting along the axis $x-y$. Very often extensions are made along $x-y$ below the lower design. On the unfolding of $x-y$ the design is complete and ready for use. From it the pattern is sketched on the leather pieces intended for the vamps. In some cases the design is sewed on free- 


\section{D ECORATIVE ART OF THE}

hand, but the bitten pattern always serves as the guide. One pattern may be used for many pairs of moccasins, and in time it becomes committed to memory.

The bitten-bark patterns appear to be common to all the peoples between Newfoundland and the Plains. Although definite conclusions of their importance cannot be considered in this paper, it may be hinted that in them perhaps lie the origins of the two main art motives of northeastern North America. As we have seen, the use of bitten-bark patterns dictates certain limits in which the general outlines of the art designs shall fall. If the bark is folded, as it seems to be wherever bark-biting is practised, a symmetry is bound to result If just one fold is made, it is impossible to avoid a duplication on each half. When a second, and in some cases a third, fold is made, the bitten element appears four and eight times respectively.

As has been said, these birch-bark patterns are very common throughout northeastern North America. Ultimately, when a sufficient number has been collected to permit a thorough study of their different types, new light may be shed on the origins of the various art motives for this part of the continent. The technologic result of a use of bittenbark patterns is a symmetry, and this seems to be not only the fundamental element of the floral designs of the Têtes de Boule, but also the basic feature of the double-curve motive, as it occurs 
among the Montagnais-Naskapi art to the east. Granted that both peoples originally had similar patterns, it would seem to be logical to suspect that entirely different interpretations might have been rendered. The eastern peoples may have been impressed by the geometrical feature of the design, and as a result may have developed their art along this line. The Têtes de Boule, and others perhaps, may have seen in the same design only elements of realism. No imagination is required to interpret in this simple symmetry a stem with leaves, a branch, or, more simply, a forked stick. On the basis of this reasoning it would seem to have been not impossible for the double-curve motive, which predominates eastward from the Rivière Trenche, and the floral design, which extends westward from the same river, to have originated from a common source. Until more becomes known, however, no definite conclusions may be drawn. Among the Têtes de Boule, it may be stated, there appears to be a noticeable trend toward a truer realism when the old conventional method of selecting the designs from the bitten patterns is dispensed with. In pl. vI are shown examples of stems to which floral elements are attached in an unsymmetrical fashion. These designs and similar ones often are to be noticed when the decoration is determined by freehand methods. 





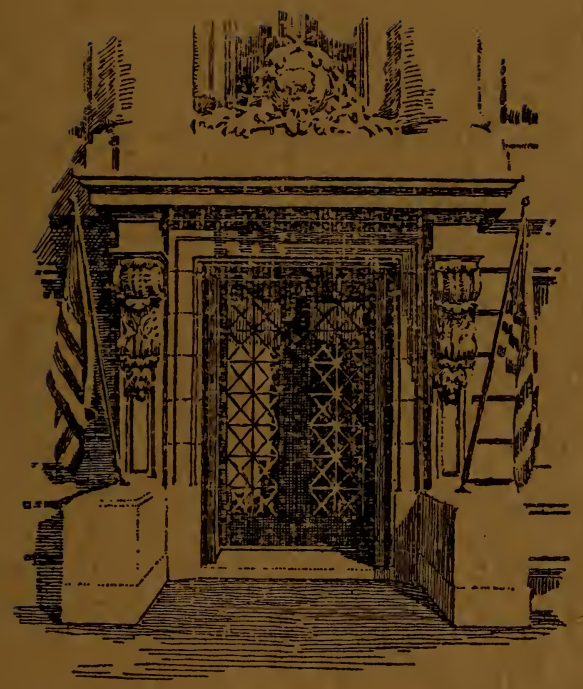


SMTTHSONLAN INSTTUTION LIBRARIES

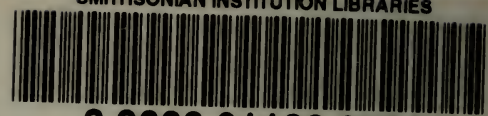

39088011863081 